\title{
IDENTIFICATION OF ENTEROTOXIGENIC STAPHYLOCOCCI IN MEAT RAW MATERIALS
}

\section{ИДЕНТИФИКАЦИЯ ЭНТЕРОТОКСИГЕННЫХ СТАФИЛОКОККОВ В МЯСНОМ СЫРЬЕ}

Bataeva D.S., Minaev M.Yu., Makhova A.A.

The V.M. Gorbatov All-Russian Meat Research Institute, Moscow, Russia

Ключевые слова: энтеротоксигенные S. aureus, контаминаиця мясного сырья, сырокопченые колбасы, идентификация.

\begin{abstract}
Аннотация
Определена необходимость обновления критериев безопасности мясного сырья, используемого для производства сырокопченых колбас. Установлено наличие в мясном сырье энтеротоксигенных штаммов S. aureus. Отработана методика и предложень ПЦР-подходь идентификации и скрининга энтеротоксигенных штаммов и их токсинов в мясном сырье. Для идентификации энтеротоксигенности выявленных стабилококков были найдены и изучены консервативные участки последовательностей генов-мишеней $S$. aитеиs, отвечающие за выработку различных видов энтеротоксинов ( $A, B, E, C, D)$. Также сконструированы короткие фрагменты нуклеиновой кислоты (праймеры), соответствующие этим выявленным генам.

В результате идентификации было установлено, что 2 выявленных штамма S. aureиs являлись энтеротоксигенными. Один из них продуцировал токсины типа А и Е (итамм NG1), а второй - токсины типа С и Е (итамм NG2). Чувствительность и специфичность метода ПЦР в реальном времени позволила проводить не только идентификаиию чистых культур, но и скрининг энтеротоксигенных итаммов и их токсинов в продукте. Даны рекомендации использовать методику в производственном контроле на наличие энтеротоксигенных штаммов S. аиreus в мясном сырье, используемом для производства сырокопченых колбас
\end{abstract}

\section{Введение}

Стафилококковые токсикозы занимают ведущее место в этиологии пищевых отравлений, например в Финляндии, Испании и США они на 1-м месте, во Франции, ФРГ, Греции, Югославии и Канаде на 2-м месте, а в Великобритании на 3-м месте [1].

Причиной пищевых интоксикаций стафилококковой этиологии являются энтеротоксины, продуцируемые энтеротоксигенными штаммами $S$. aureus. Эти микроорганизмы продуцируют шесть серологических типов токсинов: A, B, C, D, E, F.

При этом отдельные штаммы $S$. aureus могут продуцировать сразу несколько типов токсинов $[2,3,4,5]$. При алиментарном заражении летальная доза $-\mathrm{LD}_{50}=$ $4 \times 10^{-5} \mathrm{Mг} /$ кг.

Одним из источников отравления являются мясо и мясопродукты. Энтеротоксины золотистого стафи-
Keywords: enterotoxigenic S. aureus, contamination of raw meat, fermented sausages, detected.

\section{Abstract}

The need to renew the safety criteria for meat raw material used in production of fermented sausages was determined. The presence of the enterotoxigenic $S$. aureus strains in meat raw material was established. The method was mastered and the PCR approaches to identification and screenings of enterotoxigenic strains and their toxins in meat raw material were proposed. In order to identify enterotoxigenicity of detected staphylococci, the conservative regions of the $S$. aureus target gene sequences responsible for production of different types of enterotoxins $(A, B$, $E, C, D)$ were found and studied. In addition, short fragments of a nuclear acid (primers) corresponding to these revealed genes were constructed.

As a result of identification, it was established that two isolated strains of $S$. aureus were enterotoxigenic. One of them produced type $A$ and $E$ toxins (strain NG1) and another produced type $C$ and $E$ toxins (strain NG2). The sensitivity and specificity of the real-time PCR method allowed not only identification of pure cultures but also screening of enterotoxigenic strains and their toxins in a product. The use of this method in the production control for the presence of the enterotoxigenic strains of $S$. aureus in meat raw material used in fermented sausage manufacture was recommended.

\section{Introduction}

Staphylococcal toxicoses occupy the leading position in etiology of food poisoning. For example, they are ranked first in Finland, Spain and the USA, the second in France, Germany, Greece, Canada and the states of the former Yugoslavia, and the third in the UK [1].

The causes of food-borne intoxications of staphylococcal etiology are enterotoxins produced by the enterotoxigenic strains of $S$. aureus. These microorganisms produce six main serological types of toxins: A, B, C, D, E, F.

Moreover, individual S. aureus strains can produce several toxin types simultaneously $[2,3,4,5]$. Upon alimentary infection, the lethal dose is $\mathrm{LD}_{50}=$ $4 \times 10^{-5} \mathrm{mg} / \mathrm{kg}$.

One of the sources of poisoning is meat and meat products. S. aureus enterotoxins persist in meat food systems 
лококка длительно сохраняются в мясных пищевых системах даже при отсутствии бактериальных клеток, что и предопределяет возможность возникновения токсикозов.

Энтеротоксины в мясном фарше, в сыром, а также в вареном мясе могут накапливаться за 14-16 ч при температуре $35-37^{\circ} \mathrm{C}$, в паштетах — за 10-12 ч, а в готовых кулинарных мясных изделиях при комнатной температуре хранения - за 3 ч.

Контаминация мяса микроорганизмами Staphylococcus aureus может произойти при жизни животных в результате перенесенных заболеваний.

При ветеринарно-санитарной экспертизе органов и тканей убойных животных могут быть выявлены единичные или множественные абсцессы в лимфоузлах, во внутренних органах и в мышечной ткани, которые обусловлены различными инфекционными болезнями животных, (актиномикоз, коринебактериоз, псевдотуберкулез, туберкулез, стафиллококкоз и др.). Стафилококки выявляют из абсцессов поражающих органы и ткани: у крупного рогатого скота поражение составляет - 7 \% от числа обследованных туш, у свиней $-4 \%$, у овец - $13 \%$.

Золотистый стафилококк является наиболее частым возбудителем стафилококкозов среди всех стафилококков и на его долю приходится от 9 до 89\% случаев заболеваний [6].

При поступлении мясного сырья, со скрытыми внутренними абсцессами, может происходить контаминация фарша, предназначенного для производства мясных изделий. В случае производства вареных, варено-копченых колбас или консервов происходит инактивация патогенных и условно-патогенных микроорганизмов за счет тепловой обработки. В то время как, ферментированные изделия, технология которых не предусматривает высокого температурного воздействия, могут стать благоприятной средой для развития стафилококков и соответственно и причиной токсикозов.

Нормативная документация РФ не предусматривает исследования мяса на $S$. aureus и выявления энтеротоксина в готовой мясной продукции. Безопасность продукции, например сырокопченой, определяется достижением порогового уровня влаги на уровне $30 \%$ и отсутствием другого микроорганизма - E. coli в одном грамме продукта [7].

В зарубежной практике при производстве ферментированных колбас GMP существует алгоритм расчета времени ферментации по формуле

$$
\left(\mathrm{T}-60^{\circ} \mathrm{F}\right) \times \mathrm{H}
$$

где Т - температура созревания, ${ }^{\circ} \mathrm{F} ; \mathrm{H}$ - время процесса, ч; в течение которого достигается пороговая величина $\mathrm{pH}$ продукта, при которой $S$. aureus не образует энетеротоксинов.

Этот алгоритм определяет максимальное количество времени, при определенной температуре ферментации for a long time even in the absence of the bacterial cells, which predetermines a possibility of toxicosis.

Enterotoxins in minced meat, raw and cooked meat can accumulate during 14-16 hours at a temperature of 35$37^{\circ} \mathrm{C}$, in pâtés during $10-12$ hours and in ready culinary meat products during 3 hours at a room temperature.

Meat contamination with S. aureus can occur during animal life as a result of past diseases.

Upon veterinary-sanitary inspection of organs and tissues of slaughter animals, individual or multiple abscesses in the lymphatic nodes, in the internal organs and muscle tissue can be revealed, which are conditioned by various infectious diseases of animals (actinomycosis, corynebacteriosis, pseudotuberculosis, staphylococcosis and others). Staphylococci are isolated from abscesses that affect organs and tissues: in cattle, the lesions account for $7 \%$ of the inspected carcasses, in pigs for $4 \%$, in sheep for $13 \%$.

S. aureus is the most frequent infectious agent of staphylococcosis among all staphylococci and accounts for 9 to $89 \%$ cases of disease [6].

Upon entering meat raw material with hidden internal abscesses, contamination of minced meat intended for meat product manufacture can occur. In case of manufacturing cooked or cooked and smoked sausages, or canned foods, pathogenic and conditionally pathogenic microorganisms are inactivated due to thermal treatment. However, fermented products, which technology does not stipulate an exposure to a high temperature, can become a favorable environment for staphylococcal development and, therefore, a cause of toxicosis.

The normative documentation of the RF does not stipulate meat analysis for S. aureus and detection of the enterotoxin in finished meat products. Product safety in fermented products, for example, is determined by reaching a threshold moisture level of $30 \%$ and the absence of $E$. coli in one gram of a product [7].

In foreign practice, when producing fermented sausages adhering to GMP, there is an algorithm for calculation of fermentation duration according to the equation

$$
\left(\mathrm{T}-60^{\circ} \mathrm{F}\right) \times \mathrm{H} \text {, }
$$

where $\mathrm{T}$ is a temperature of ageing, ${ }^{\circ} \mathrm{F} ; \mathrm{H}$ - process time, $\mathrm{h}$, during which a product reaches the threshold $\mathrm{pH}$ value, at which S. aureus does not produce enterotoxins.

This algorithm determines maximum time at a specific sausage fermentation temperature, during which the $\mathrm{pH}$ 
колбас, за которое $\mathrm{pH}$ продукта должно снизиться до значения 5,3. Это значение выражается в произведении « ${ }^{\circ} \mathrm{F} /$ часы». Температура в этой формуле определяется как разница между температурой созревания и «60 ${ }^{\circ} \mathrm{F}$ нижней границей температуры, при которой возможно образование стафилококковых энтеротоксинов [8]. Так при соотношении « ${ }^{\circ} \mathrm{F} /$ часы», равном 1200 при температуре « $75^{\circ} \mathrm{F}$ » время, за которое $\mathrm{pH}$ сырья должен снизиться до 5,3 составляет 80 ч, а для « ${ }^{\circ} \mathrm{F} /$ час», равном 900 при « $110^{\circ} \mathrm{F} »$ это время составит 18 ч.

Известно, что критическим фактором экспрессии стафилококкового энтеротоксина, помимо рН, являются фазы роста стафилококковых клеток [9]. Наиболее интенсивно энтеротоксины накапливается на стадии логарифмического роста, когда количество клеток достигает значения $10^{6}-10^{8} \mathrm{KOE} / г$. При таких значениях КОЕ/г величина рН уже не оказывает лимитирующего воздействия на рост некоторых штаммов $S$. aureus.

Поэтому при производстве ферментированных мясных изделий необходимо контролировать количество S. aureus в мясе и стафилококкового энтеротоксина в готовых изделиях, особенно если процесс ферментации протекал при температурах выше $16^{\circ} \mathrm{C}$ или имела место низкая скорость снижения $\mathrm{pH}$. Поиск оптимальных условий предотвращения роста загрязнения продукции штамма S. aureus и последующего накопления энтеротоксинов является важнейшей задачей получения безопасной пищевой продукции.

Целью работы являлась разработка методики определения энтеротоксигенных стафилококков в мясном сырье, предназначенного для производства ферментированных колбас.

\section{Материалы и методы}

Для выбора наиболее оптимальных условий культивирования при выявлении S. aureus в продукции с высоким содержанием коагулазонегативных стафилококков (входящих в состав стартовых культур) было проведено исследование сначала на тест-штаммах, а затем на двух модельных мясных системах с естественным содержанием S.aureus, которые были отобраны в рамках предыдущей работы, описанной в статье [10] .

Тест-штаммы были представлены смесью S. aureus и S. carnosus в соотношении $2 \times 10^{4}$ и $2 \times 10^{7} \mathrm{KOE} / \mathrm{cm}^{3}$ соответственно. Исходные суспензии двух микроорганизмов были приготовлены с использованием стандарта мутности МакФарланда. После приготовления микробной смеси производили посев ее на поверхность маннитол солевого агара с желточной эмульсией (MCA) с помощью бактериальной петли объемом 5 мкл.

Модельные мясные системы были представлены измельченным мясным сырьем, подготовленным для производства сырокопченых колбас. Из навесок модельных мясных систем массой 25,0 г готовили первичные value of a product should drop to 5.3. This value is expressed in ${ }^{\circ} \mathrm{F} /$ hours. The temperature in this equation is determined as a difference between an ageing temperature and $60^{\circ} \mathrm{F}$, which is the lower temperature limit for production of staphylococcal enterotoxins [8]. For instance, at the ${ }^{\circ} \mathrm{F} /$ hours ratio equal to 1200 at a temperature of $75^{\circ} \mathrm{F}$, the time for a reduction in raw material $\mathrm{pH}$ to 5.3 is 80 hours; this time is 18 hours when ${ }^{\circ} \mathrm{F} /$ hours is equal to 900 at $110^{\circ} \mathrm{F}$.

It is known that a critical factor of staphylococcal enterotoxin expression besides $\mathrm{pH}$ is growth phases of staphylococcal cells [9]. Enterotoxins are accumulated more intensively at the stage of the logarithmic growth, when the numbers of cells reach $10^{6}-10^{8} \mathrm{CFU} / \mathrm{g}$. At such levels of $\mathrm{CFU} / \mathrm{g}$, a $\mathrm{pH}$ value does not have a limiting effect on growth of several S. aureus strains.

Therefore, in production of fermented meat products, it is necessary to control the number of $S$. aureus in meat and the staphylococcal enterotoxin in finished products, especially, when a fermentation process occurs at temperatures higher than $16^{\circ} \mathrm{C}$ or at low rate of $\mathrm{pH}$ reduction. A search for optimal conditions for prevention of product contamination with $S$. aureus strains and subsequent accumulation of enterotoxins is the most important task in manufacturing safe food products.

The aim of this work was to develop a method for detection of the enterotoxigenic staphylococci in meat raw material intended for manufacturing fermented sausages.

\section{Materials and methods}

To choose the most optimal culturing conditions when detecting S. aureus in products with high content of coagulase-negative staphylococci (being constituents of starter cultures), a study was initially carried out on the test strains and then on two model meat systems with natural contamination levels of S. aureus, which were selected in the framework of the previous research described in [10].

The test strains were presented by a mixture of S.aureus and S.carnosus in a ratio of $2 \times 10^{4}$ and $2 \times 10^{7} \mathrm{CFU} / \mathrm{cm}^{3}$, respectively. The initial suspensions of two microorganisms were prepared using the McFarland standard. After preparation of the microbial mixture, it was inoculated onto the surface of Mannitol Salt Agar with egg yolk emulsion (MSA) using a bacterial loop with a volume of $5 \mu \mathrm{l}$.

The model meat systems were presented by minced meat raw material prepared for production of fermented sausages. The initial suspensions were prepared from the specimens of the model minced systems with a weight of 
суспензии с последующей нейтрализацией. Навеска массой 25,0 г была взята с целью выявления малых количеств S. aureus. В качестве разбавителя использовали маннитол-солевой бульон (МСБ) с рН индикатором. Использование разбавителя с $\mathrm{pH}$ индикатором позволило избежать использования стерильных буферных систем. Был использован индикатор феноловый красный. Для нейтрализации исходной суспензии добавляли 1,0 М раствор гидроксида натрия ( $\mathrm{NaOH})$. Пересев с жидкой питательной среды (МСБ) на плотную среду (МСА) проводили только после изменения цвета культивируемой жидкости с малинового на желтый.

Посевы культивировали в аэробных и в анаэробных условиях при температуре $37^{\circ} \mathrm{C}$ в течение 24-48 ч.

Колонии микроорганизмов с зоной лецитиназной активности, выросшие МСА, были идентифицированы методом ПЦР в реальном времени. Амплификацию проводили на приборе ABI PRISM 7000 Applied Biosystems (США).

При постановке ПЦР использовали ген-специфичные праймеры на выявление энтеротоксинов типов: A, B, C, D и Е.

Выбранные праймеры были синтезированы $3 \mathrm{AO}$ «Синтол, г. Москва» фосфоамитидным методом на синтезаторе ASM-102.

Анализ хромосомной и плазмидной ДНК объектов и поиск их нуклеотидных последовательностей проводили по генетической базе Национального центра биотехнологической информации США (National Center for Biotechnological Information, NCBI), которая находится в сети Интернет [11].

Анализ выбранных нуклеотидных последовательностей на вариабельность и поиск консервативных участков, необходимых для выбора праймеров проводили с помощью компьютерных программ CLC Sequence Viewer и Primer Express 2 (Applied Biosystems, США). Специфичность выбранных праймеров анализировали с помощью интерактивной системы BLAST on-line [12].

В качестве отрицательного контроля системы использовали пробу не содержащую ДНК определяемых биологических объектов.

\section{Результаты и обсуждение}

При сравнении результатов роста на двух параллельных посевах (рисунок 1 и рисунок 2), установлено, что только при анаэробном культивировании рост S. aureus доминирует над ростом S. carnosus даже при исходном преобладании в смеси последнего. При аэробном культивировании происходит преобладание роста S. carnosus, что, в свою очередь затрудняет выявление S. aureus.

Результаты аналогичного исследования но уже модельной мясной системы представлены на рисунке 3 и рисунке 4.

Как видно из рисунка 3 и рисунка 4 при культивировании посевов в аэробных условиях, доминирующая микрофлора представлена коагулазоотрицатель-
$25.0 \mathrm{~g}$ with subsequent neutralization. A specimen with a weight of $25.0 \mathrm{~g}$ was taken with the aim of detecting low numbers of S. aureus. The Mannitol Salt broth (MSB) with a $\mathrm{pH}$ indicator was used as a dilutant. The use of the dilutant with a $\mathrm{pH}$ indicator allowed us to avoid using sterile buffer systems. The indicator phenol red was used. For neutralization of the initial suspension, 1.0 M sodium hydroxide $(\mathrm{NaOH})$ solution was added. A transfer from the liquid growth medium (MSB) to the solid growth medium (MSA) was carried out only after changing the color of the culture liquid from raspberry to yellow.

The plates were incubated in the aerobic and anaerobic conditions for $24-48$ hours at a temperature of $37^{\circ} \mathrm{C}$.

The colonies of microorganisms grown on MSA and showing the zones of the lecithinase activity were identified by the real-time PCR method. Amplification was carried out using an apparatus ABI PRISM 7000 Applied Biosystems (USA).

In PCR, the gene-specific primers for detection of enterotoxins (types A, B, C, D and E) were used.

The chosen primers were synthesized by ZAO «Sintol» (Moscow) by phosphoamitide method on a synthesizer ASM-102.

An analysis of the chromosomal and plasmid DNA of the objects and a search for their nucleotide sequences were carried out using the genetic base of the National Center for Biotechnological Information (NCBI) via the Internet [11].

An analysis of the chosen nucleotide sequences for variability and a search for conservative regions that are necessary for selecting primers were performed using CLC Sequence Viewer and Primer Express 2 (Applied Biosystems, US). Specificity of the chosen primers was analyzed using the interactive system BLAST on-line [12].

A sample without DNA of the objects under investigation was used as a negative control.

\section{Results and discussion}

When comparing the results of growth on two parallel plates (Fig. 1 and Fig. 2), it was established that S. aureus growth dominated over S. carnosus growth only during anaerobic incubation even in case of initial domination of the latter in a mixture. During aerobic incubation, S. carnosus dominated, which, in turn, hindered detection of $\mathrm{S}$. aureus.

Fig. 3 and Fig. 4 present the results of the similar investigation, but in this case with the use of the model meat system.

As can be seen from Fig. 3 and Fig. 4, upon aerobic incubation of the plates, the dominant microflora was presented by coagulase-negative staphylococci, namely, 
ными стафилококками, а именно S.carnosus, которые были внесены в модельную мясную систему в качестве стартовой культуры (рисунок 3). Однако при анаэробном культивировании наблюдалось преобладание роста уже S. aureus (рисунок 4).

На основании полученных результатов, для выявления S. aureus из мясного сырья, предназначенного для производства ферментированной колбасы, рекомендуется проводить культивирование в строго анаэробных условиях.

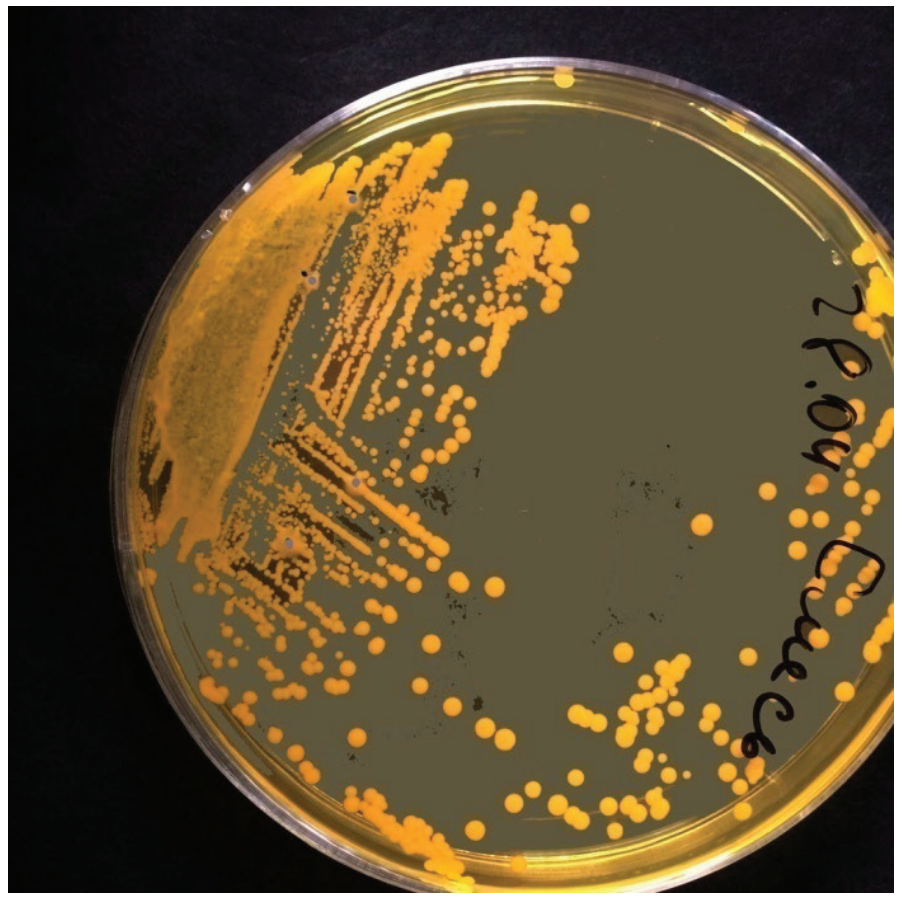

Figure 1. Aerobic incubation of the mixed culture of S. aureus and S. carnosus

Рис. 1. Аэробное культивирование смешанной культуры S. aureus и S. carnosus

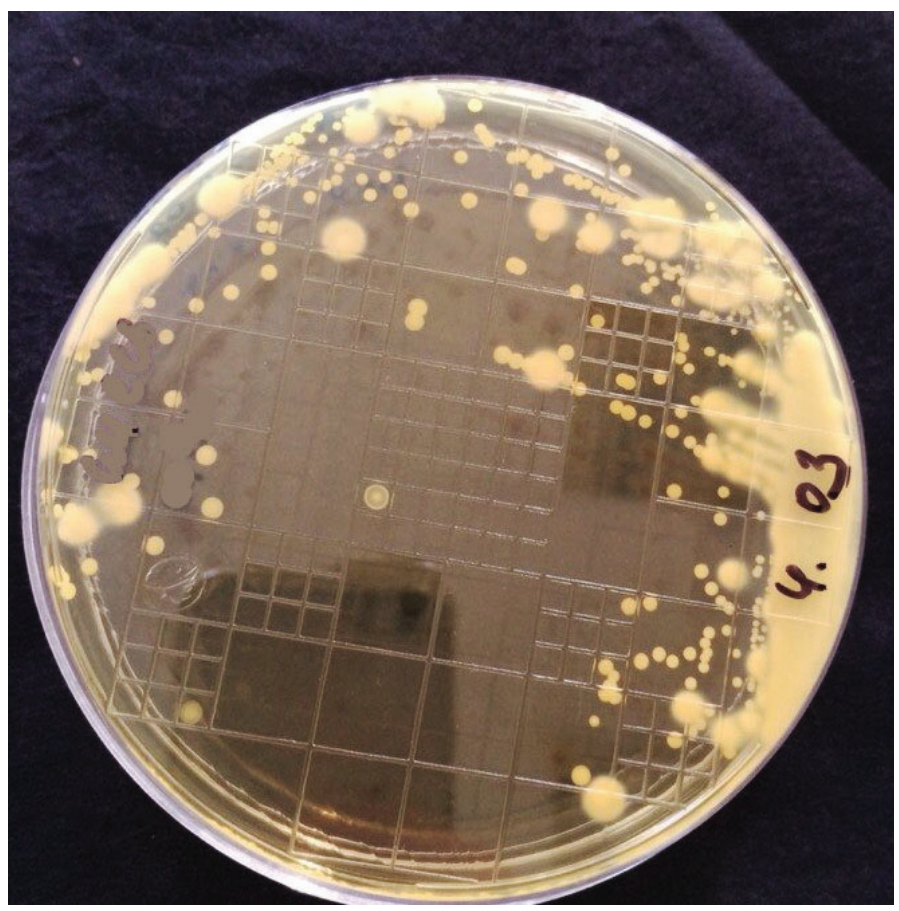

Figure 3. Aerobic incubation of microorganisms on MSA Рис. 3. Аэробное культивирование на МСА микроорганизмов
S.carnosus, which was inoculated in the model meat system as a starter culture (Fig. 3). However, during anaerobic incubation, domination of $\mathrm{S}$. aureus growth was observed (Fig. 4).

On the basis of the obtained results, incubation in strictly anaerobic conditions is recommended in order to detect $\mathrm{S}$. aureus from meat raw material intended for production of fermented sausages.

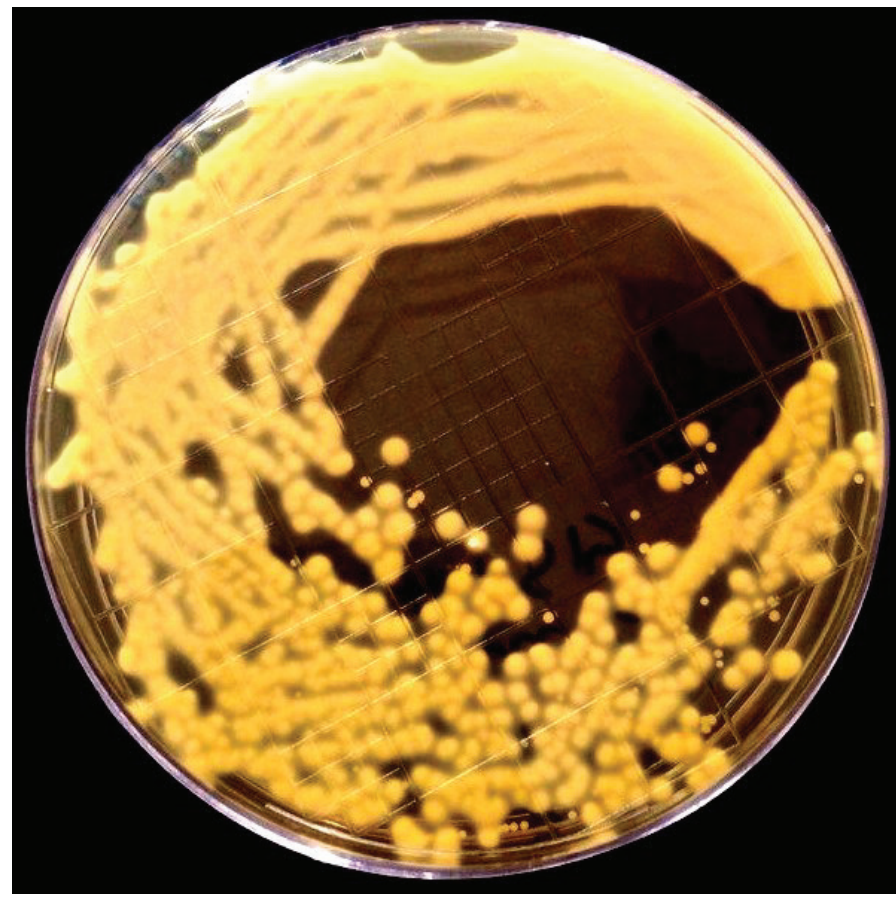

Figure 2. Anaerobic incubation of the mixed culture of S. aureus and S. carnosus

Рис. 2. Анаэробное культивирование смешанной культуры S. aureus и $S$. carnosus

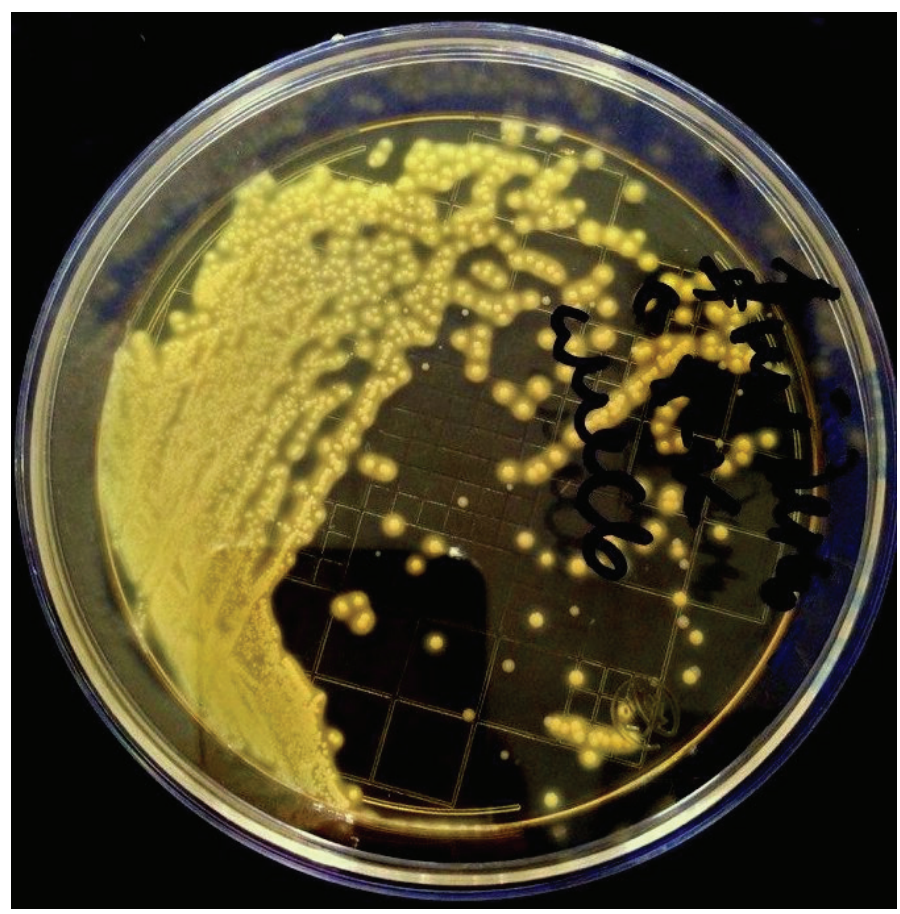

Figure 4. Anaerobic incubation of microorganisms on MSA Рис. 4. Анаэробное культивирование на МСА микроорганизмов 
Для идентификации энтеротоксигенности выявленных стафилококков были найдены и изучены консервативные участки последовательностей генов-мишеней S. aureus, отвечающие за выработку различных видов энтеротоксинов (A, B, E, C, D). Также сконструированы короткие фрагменты нуклеиновой кислоты (праймеры), соответствующие этим выявленным генам.

В результате идентификации методом ПЦР было установлено, что 2 выявленных штамма S. aureus являлись энтеротоксигенными. Один из них продуцировал токсины типа А и Е (штамм NG1), а второй — токсины типа С и Е (штамм NG2).

Кривые амплификации и плавления ДНК двух энтеротоксигенных штаммов S. aureus NG1 и NG2, представлены на рисунках 5-8.

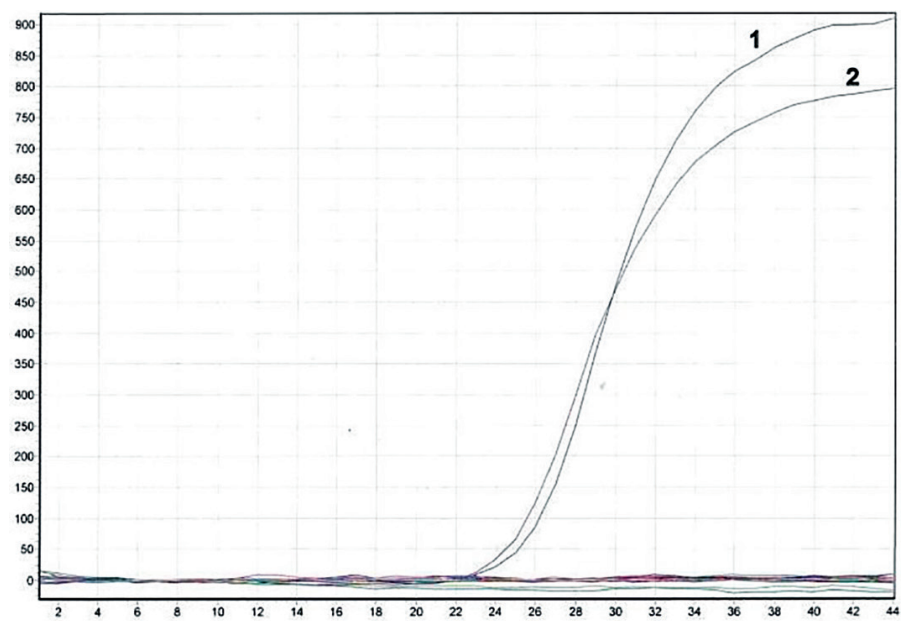

Fig 5. DNA amplification curves for enterotoxigenic $S$. aureus strain NG1: 1 - positive reaction on the enterotoxin A gene; 2 - positive reaction on the enterotoxin $\mathrm{E}$ gene; 3 - negative control

Рис. 5. Кривые амплификации ДНК энтеротоксигенного штамма S. aureus NG1: 1 - положительная реакция на ген энтеротоксина A; 2 - положительная реакция на ген энтеротоксина E; 3 - отрицательный контроль

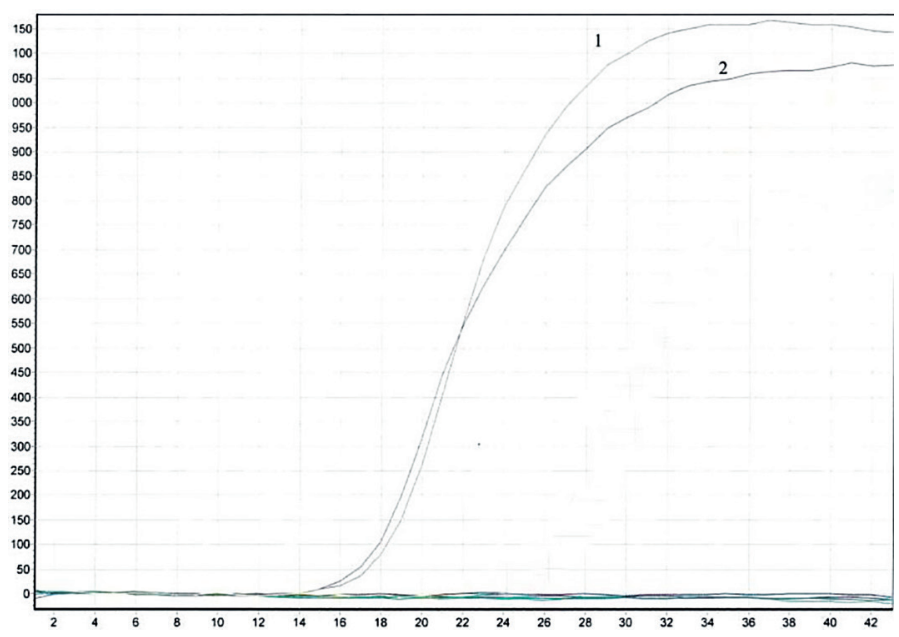

Fig 7. DNA amplification curves for enterotoxigenic S. aureus strain NG2: 1 - positive reaction on enterotoxin $C$ gene; 2 - positive reaction on enterotoxin E gene; 3 - negative control

Рис. 7. Кривые амплификации ДНК энтеротоксигенного штамма S. aureus NG2: 1 - положительная реакция на ген энтеротоксина C; 2 - положительная реакция на ген энтеротоксина $\mathrm{E}$
To identify enterotoxigenicity of the isolated staphylococci, the conservative regions of the $S$. aureus target gene sequences, which were responsible for production of different types of enterotoxins (A, B, E, C, D), were found and studied. In addition, the short fragments of a nucleic acid (primers) corresponding to these revealed genes were constructed.

As a result of identification by the PCR method, it was established that two isolated $S$. aureus strains were enterotoxigenic. One of them produced the toxins type $\mathrm{A}$ and $\mathrm{E}$ (strain NG1), the second produced the toxins type $\mathrm{C}$ and $\mathrm{E}$ (strain NG2).

The DNA amplification and melting curves for two enterotoxigenic $S$. aureus strains NG1 and NG2 are presented in Fig. 5-8.

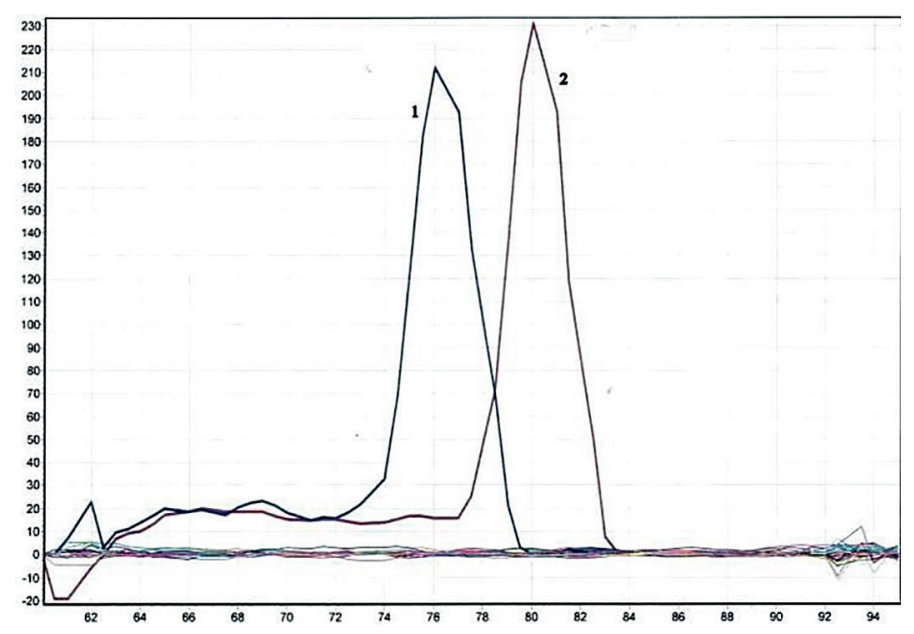

Fig 6. DNA melting curves for enterotoxigenic S. aureus strain NG1: 1 - positive reaction on the enterotoxin A gene; 2 - positive reaction on the enterotoxin E gene; 3 - negative control

Рис. 6. Кривые плавления ДНК энтеротоксигенного штамма S. aureus NG1: 1 - положительная реакция на ген энтеротоксина A; 2 - положительная реакция на ген энтеротоксина E; 3 отрицательный контроль

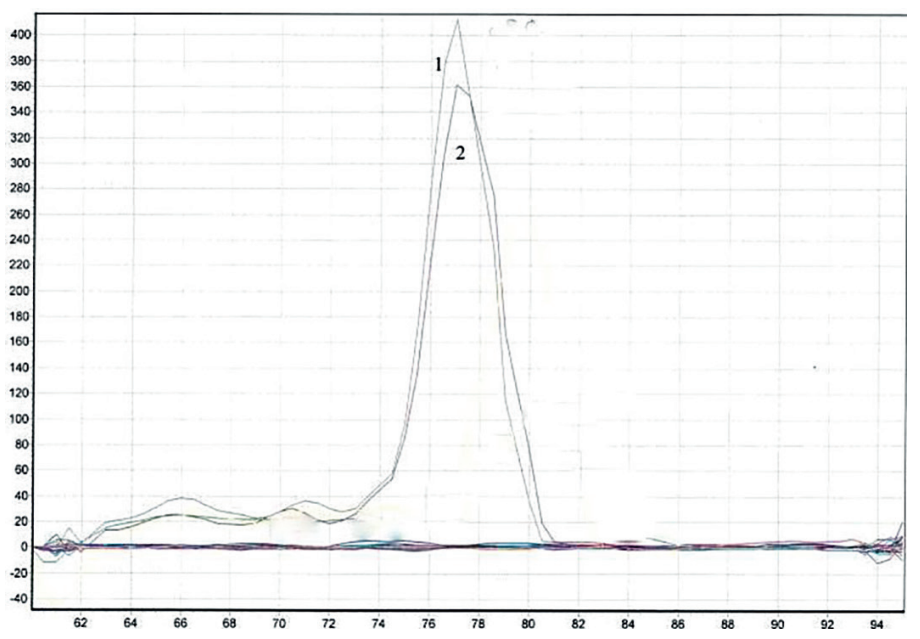

Fig 8. DNA melting curves for enterotoxigenic $S$. aureus strain NG2: 1 - positive reaction on enterotoxin $\mathrm{C}$ gene; 2 - positive reaction on enterotoxin E gene; 3 - negative control

Рис. 8. Кривые плавления ДНК штамма S. aureus NG2: 1 - положительная реакция на ген энтеротоксина C; 2 - положительная реакция на ген энтеротоксина $\mathrm{E}$ 
Успешность амплификации с подобранными праймерами для идентификации генов энтеротоксинов типа А, С и Е представлена на рис. 5 и 7, специфичность реакции подтверждена кривыми плавления, представленных на рис. 6 и 8. На кривых плавления видны два четко выраженных пика, которые соответствуют температурам отжига праймеров на участках генов энтеротоксинов типа А и $\mathrm{E}-76 \pm 1^{\circ} \mathrm{C}$ и $80 \pm 1^{\circ} \mathrm{C}$ соответственно, а энтеротоксина типа $\mathrm{C}-79 \pm 1^{\circ} \mathrm{C}$, что совпало с теоретическим расчетом по данным ампликонам.

В результате проведенных исследований было установлено, что оба выделенных штамма являлись мультитоксигенными, т.е. содержали в своем геноме помимо гена энтеротоксина Е, один штамм еще ген энторотоксина A (штамм NG1), а второй - ген энтеротоксина C (штамм NG2).

Данная проблема актуальна в мире и поэтому ведутся исследования в этом направлении. Например, в Словакии из 43 штаммов стафилококков, выделенных из различных пищевых продуктов, 15 штаммов $(34,88 \%)$ оказались энтеротоксигенными и 7 (16,28\%) из них содержали энтеротоксин типа А [13]. Оценка 444 образцов мяса, проведенная в Японии показала, что в 65,8\% образцах были обнаружены S. aureus из которых 17,9 \% штаммов продуцировали энтеротоксин только типа A, 2,6\% штаммов - типы $\mathrm{A}+\mathrm{B}$ и 2,6\% штаммов - A + С энтеротоксины [14].

Таким образом, есть риск использования мяса с энтеротоксигенными штаммами S. aureus при выработке сырокопченых колбас, что чревато образованием и накоплением в них токсинов. Как известно, стафилококковые энтеротоксины являются термостабильными и инактивируются при кипячении только через $2,5-3,0$ часа, а при автоклавировании при $120^{\circ} \mathrm{C}$ в течение 20 мин.

Результаты исследований по оптимизации условий культивирования показали, что анаэробные условия культивирования посевов позволяют увеличить селективность и специфичность селективной обогатительной среды (МСБ) и селективной среды для выделения (MCA) S. aureus, что позволит выявить S. aureus из продукции изготовленной с применением стартовых культур, имеющих в своем составе коагулазонегативные стафилококки.

Также нами были разработаны праймеры, позволяющие методом ПЦР идентифицировать энтеротоксигенные S. aureus. Чувствительность и специфичность метода ПЦР в реальном времени позволяет проводить не только идентификацию чистых культур, но и скрининг энтеротоксигенных штаммов в продукте с определением типа продуцируемого им токсина. Это подтверждается и в работах других исследователей, которые подтверждают что метод ПЦР может лишь подтвердить наличие в продукте энтеротоксигенных штаммов, но не определять нали-
Successful amplification with the selected primers for identification of the enterotoxin A, C and $\mathrm{E}$ genes is presented in Fig. 5 and Fig. 7; specificity of the reaction is proved by the melting curves presented in Fig. 6 and Fig. 8 . In the melting curves, two clearly pronounced peaks can be seen, which correspond to the primer annealing temperatures at the sites of the genes for enterotoxins type $\mathrm{A}$ and $\mathrm{E}\left(76 \pm 1^{\circ} \mathrm{C}\right.$ and $80 \pm 1^{\circ} \mathrm{C}$, respectively) and enterotoxin type $\mathrm{C}\left(79 \pm 1^{\circ} \mathrm{C}\right)$, which coincides with the theoretical calculations for these amplicons.

As a result of the performed research, it was established that both isolated strains were multitoxigenic; that is, they contained in their genome the enterotoxin A gene (strain NG1) and the enterotoxin C gene (strain NG2) in addition to enterotoxin E gene.

This problem is topical worldwide and, therefore, the studies are carried out in this field. For example, in Slovakia, among 43 staphylococcal strains isolated from different foods, 15 strains (34.88\%) were enterotoxigenic and 7 (16.28\%) of them contained enterotoxin type A [13]. An analysis of the 444 meat samples performed in Japan showed that $65.8 \%$ of samples contained S. aureus, of which $17.9 \%$ strains produced enterotoxin type A, $2.6 \%$ strains produced enterotoxin types $\mathrm{A}+\mathrm{B}$ and $2.6 \%$ strains produced enterotoxin types A + C [14].

Thus, there is a risk of using meat with enterotoxigenic strains of $\mathrm{S}$. aureus when manufacturing fermented sausages, which can result in production and accumulation of toxins in these products. It is known that staphylococcal enterotoxins are heat-stable and are inactivated upon boiling only after 2.5-3.0 hours and when autoclaving at $120^{\circ} \mathrm{C}$ during $20 \mathrm{~min}$.

The results of the study on optimization of the incubation conditions demonstrated that anaerobic incubation conditions allow increasing selectivity and specificity of the selective enrichment medium (MSB) and selective medium for isolation (MSA), which allows isolation of S. aureus from products manufactured with the use of starter cultures having coagulase-negative staphylococci in their composition.

We also designed primers that allowed identification of enterotoxigenic S. aureus by the PCR method. The sensitivity and specificity of the real-time PCR method make it possible not only to identify pure cultures but to screen enterotoxigenic strains in a product with determination of an enterotoxin type produced by them. This is also confirmed by the works of other researchers, who proved that the PCR method can only confirm the presence of enterotoxigenic strains in a product, but does not detect the pres- 
чие токсина [15]. Для определения токсинов используют ИФА тест-системы. Приборное обеспечение для проведения ИФА это прибор miniVidas (фирмы Биомерье, Франция).

Обозначив риски при производстве сырокопченых колбас и предложив методы их контроля, рекомендуем ввести в программу производственного контроля следующие показатели: энтеротоксигенные S. aureus в мясном сырье и стафилококковые энтеротоксины в готовой продукции.

\section{Выводы}

Для идентификации энтеротоксигенности выявленных стафилококков были найдены и изучены консервативные участки последовательностей генов-мишеней S. aureus, отвечающие за выработку различных видов энтеротоксинов (A, B, E, C, D). Также сконструированы короткие фрагменты нуклеиновой кислоты (праймеры), соответствующие этим выявленным генам.

В результате идентификации было установлено, что 2 выявленных штамма S. aureus являлись энтеротоксигенными. Один из них продуцировал токсины типа А и Е (штамм NG1), а второй - токсины типа C и Е (штамм NG2).

Из-за существующих технологических рисков при производстве сырокопченых колбас необходимо обновить критерии безопасности и ввести их в программу производственного контроля.

\section{БИБЛИОГРАФИЧЕСКИИ СПИСОК}

1. Sarkar A.A. Antimicrobial resistance and virulence markers in methicillin sensitive Staphylococcus aureus isolates associated with nasal colonization // A. Sarkar, A. Raji, G. Garaween, O. Soge, J. Rey-Ladino, W. Al-Kattan, A. Shibl, A. Senok - Microbial Pathogenesis. - 2016. - V. 93. - № 4. - P. 8-12.

2. Cremonesi P. Genomic characteristics of Staphylococcus aureus strains associated with high within-herd prevalence of intramammary infections in dairy cows // P. Cremonesi, F. Pozzi, M. Raschetti, G. Bignoli, E. Capra, H.U. Graber, F. Vezzoli, R. Piccinini, B. Bertasi, S. Biffani, B. Castiglioni, M. Luini - Journal of Dairy Science. - 2015. - V. 98. - № 10. - P. 6828-6838.

3. Bar-Gal G.K. Host-specificity of Staphylococcus aureus causing intramammary infections in dairy animals assessed by genotyping and virulence genes // G.K. Bar-Gal, S.E. Blum, L. Hadas, R. Ehricht, S. Monecke, G. Leitner - Veterinary Microbiology. 2015. - V. 176. - № 1-2. - P. 143-154.

4. Budd K.E. Lineage associated expression of virulence traits in bovine-adapted Staphylococcus aureus // K.E. Budd, J. Mitchell, 0.M. Keane - Veterinary Microbiology. - 2016. - V. 189. № 6. - P. 24-31.

5. Bardiau M., Caplin J., Detilleux J., Graber H., Moroni P., Taminiau B., Mainil J.G. Existence of two groups of Staphylococcus aureus strains isolated from bovine mastitis based on biofilm formation, intracellular survival, capsular profile and agr-typing // M. Bardiau, J. Caplin, J. Detilleux, H. Graber, P. Moroni, B. Taminiau, J.G. Mainil - Veterinary Microbiology. - 2016. - V. 185. № 3. - P. 1-6.

6. Lundberg A. Udder infections with Staphylococcus aureus, Streptococcus dysgalactiae, and Streptococcus uberis at calving in dairy herds with suboptimal udder health // A. Lundberg, A.K. Nyman, A. Aspan, S. Borjesson, H.E. Unnerstad, K.P. - Waller Journal of Dairy Science. - 2016. - V. 99. - № 3. - P. 2102-2117. 7. Monecke S. Genotyping of Staphylococcus aureus isolates from diseased poultry // S. Monecke, A. Ruppelt, S. Wendlandt, S. Schwarz, P. Slickers, R. Ehricht, S.C. de Jäckel - Veterinary Microbiology. - 2013. - V. 162. - № 2-4. - P. 806-812. ence of a toxin [15]. To detect toxins ELISA test-systems are used. The instrumentation for performing ELISA is an apparatus miniVidas (bioMérieux, France).

After identifying the risks in fermented sausage manufacture and proposing the methods of their control, we recommend introducing the following indicators in the program of the production control: enterotoxigenic S. aureus in meat raw material and staphylococcal enterotoxins in finished products.

\section{Conclusions}

To identify enterotoxigenicity of the isolated staphylococci, the conservative regions of the $S$. aureus target gene sequences, which are responsible for production of different types of enterotoxins (A, B, E, C, D), were found and studied. In addition, the short fragments of a nucleic acid (primers) corresponding to these revealed genes were constructed.

As a result of the identification by PCR method, it was established that two isolated $S$. aureus strains were enterotoxigenic. One of them produced toxins type $\mathrm{A}$ and $\mathrm{E}$ (strain NG1), the second produced toxins type $\mathrm{C}$ and $\mathrm{E}$ (strain NG2).

Due to the existing technological risks in fermented sausage manufacture, it is necessary to renew the safety criteria and introduce them into the program of the production control.

\section{REFERENCES}

1. Sarkar A.A. Antimicrobial resistance and virulence markers in methicillin sensitive Staphylococcus aureus isolates associated with nasal colonization // A. Sarkar, A. Raji, G. Garaween, 0. Soge, J. Rey-Ladino, W. Al-Kattan, A. Shibl, A. Senok - Microbial Pathogenesis. - 2016. - V. 93. - № 4. - P. 8-12.

2. Cremonesi P. Genomic characteristics of Staphylococcus aureus strains associated with high within-herd prevalence of intramammary infections in dairy cows // P. Cremonesi, F. Pozzi, M. Raschetti, G. Bignoli, E. Capra, H.U. Graber, F. Vezzoli, R. Piccinini, B. Bertasi, S. Biffani, B. Castiglioni, M. Luini - Journal of Dairy Science. - 2015. - V. 98. - № 10. - P. 6828-6838.

3. Bar-Gal G.K. Host-specificity of Staphylococcus aureus causing intramammary infections in dairy animals assessed by genotyping and virulence genes // G.K. Bar-Gal, S.E. Blum, L. Hadas, R. Ehricht, S. Monecke, G. Leitner - Veterinary Microbiology. 2015. - V. 176. - № 1-2. - P. 143-154.

4. Budd K.E. Lineage associated expression of virulence traits in bovine-adapted Staphylococcus aureus // K.E. Budd, J. Mitchell, O.M. Keane - Veterinary Microbiology. - 2016. - V. 189. № 6. - P. 24-31.

5. Bardiau M., Caplin J., Detilleux J., Graber H., Moroni P., Taminiau B., Mainil J.G. Existence of two groups of Staphylococcus aureus strains isolated from bovine mastitis based on biofilm formation, intracellular survival, capsular profile and agr-typing // M. Bardiau, J. Caplin, J. Detilleux, H. Graber, P. Moroni, B. Taminiau, J.G. Mainil - Veterinary Microbiology. - 2016. - V. 185. № 3. - P. 1-6.

6. Lundberg A. Udder infections with Staphylococcus aureus, Streptococcus dysgalactiae, and Streptococcus uberis at calving in dairy herds with suboptimal udder health // A. Lundberg, A.K. Nyman, A. Aspan, S. Borjesson, H.E. Unnerstad, K.P. - Waller Journal of Dairy Science. - 2016. - V. 99. - № 3. - P. 2102-2117. 7. Monecke S. Genotyping of Staphylococcus aureus isolates from diseased poultry // S. Monecke, A. Ruppelt, S. Wendlandt, S. Schwarz, P. Slickers, R. Ehricht, S.C. de Jäckel - Veterinary Microbiology. - 2013. - V. 162. - № 2-4. - P. 806-812. 
8. Marianski A. Meat Smoking and smokehouse design // A. Marianski, R. Marianski, S. Marianski. - British Columbia: English. Publisher. Bookmagic, LLC. - 2009. - P. 324.

9. Marianski A. The art of making fermented sausages // A. Marianski, S. Marianski - Grand Rapids, MI, United States, 2010. - P. 272

10. Минаев М.Ю., Батаева А.С., Еремцова А.А. Технологические риски при производстве сухих сырокопченых колбас // Мясная индустрия. -2015 . - № 12. - С. 24-28.

11. http://ncbi.nIm.nih.gov/.

12. Электронный ресурс www.ncbi.nIm.nih.gov/Blast.

13. Holeckova B., Holoda E., Fotta M., Kalinacova V., Gondol J., Grolmus J. Occurrence of enterotoxigenic Staphylococcus aureus in food. Ann Agric Environ Med. 2002; 9(2): 179-82.

14. Kitai S., Shimizu A., Kawano J., Sato E., Nakano C., Kitagawa H., et al. Prevalence and characterization of Staphylococcus aureus and enterotoxigenic Staphylococcus aureus in retail raw chicken meat throughout Japan. J Vet Med Sci. 2005; 67(3): 269-74.13. 15. Imani F.A., Iman I.D., Hosseini D.R., Karami A., Marashi S.M. Design of a multiplex PCR method for detection of toxigenicpathogenic in Vibrio cholerae. Asian Pac J Trop Med. 2013; 6(2): 115-8.
8. Marianski A. Meat Smoking and smokehouse design // A. Marianski, R. Marianski, S. Marianski. - British Columbia: English. Publisher. Bookmagic, LLC. - 2009. - P. 324.

9. Marianski A. The art of making fermented sausages // A. Marianski, S. Marianski - Grand Rapids, MI, United States, 2010. - P. 272.

10. Minaev M.Yu., Bataeva D.S., Eremtsova A.A. Technological risks in production of dry fermented sausages // Meat industry. 2015. - № 12. - P. $24-28$.

11. http://ncbi.nlm.nih.gov/.

12. Electronic resource www.ncbi.nIm.nih.gov/Blast.

13. Holeckova B., Holoda E., Fotta M., Kalinacova V., Gondol J., Grolmus J. Occurrence of enterotoxigenic Staphylococcus aureus in food. Ann Agric Environ Med. 2002; 9(2): 179-82.

14. Kitai S., Shimizu A., Kawano J., Sato E., Nakano C., Kitagawa H., et al. Prevalence and characterization of Staphylococcus aureus and enterotoxigenic Staphylococcus aureus in retail raw chicken meat throughout Japan. J Vet Med Sci. 2005; 67(3): 269-74.13. 15. Imani F.A., Iman I.D., Hosseini D.R., Karami A., Marashi S.M. Design of a multiplex PCR method for detection of toxigenicpathogenic in Vibrio cholerae. Asian Pac J Trop Med. 2013; 6(2): 115-8.

\section{СВЕДЕНИЯ ОБ АВТОРАХ}

Принадлежность к организации

Батаева Дагмара Султановна - кандидат технических наук, доцент, руководитель направления микробиологии, ведущий научный сотрудник лаборатории «Гигиена производства и микробиология», Всероссийский научно-исследовательский институт мясной промышленности имени В.М. Горбатова

109316, г. Москва, ул. Талалихина, 26

Тел.: 8-495-676-60-11

E-mail: b.dagmara@inbox.ru

Минаев Михаил Юрьевич - кандидат технических наук, руководитель ПЦР направления, ведущий научный сотрудник лаборатории «Гигиена производства и микробиология», Всероссийский научно-исследовательский институт мясной промышленности имени В.М. Горбатова

109316, г. Москва, ул. Талалихина, 26

Тел.: 8-495-676-60-11

E-mail: mminaev@inbox.ru

Махова Анжелика Александровна - младший научный сотрудник лаборатории «Гигиена производства и микробиологии», Всероссийский научно-исследовательский институт мясной промышленности имени B.М. Горбатова

109316 г. Москва, ул. Талалихина 26,

Тел.: 8-495-676-60-11

E-mail: aeremtsova@gmail.com

\section{Критерии авторства}

Авторы в равных долях имеют отношение к написанию рукописи и одинаково несут ответственность за плагиат

Батаева Д.С. разрабатывала научно-методические подходы к проведению работ, определяла объем исследований, анализировала полученные данные, выполняла описательную часть и корректировала после подачи в редакцию

Минаев М.Ю. разрабатывал научно-методические подходы к проведению работ, определяла объем исследований, анализировала полученные данные

Махова А.А. отбирала объекты исследования, выполняла исследования.

\section{Конфликт интересов}

Авторы заявляют об отсутствии конфликта интересов.

Поступила 25.10.2016

\section{AUTOR INFORMATION}

\section{Affiliation}

Bataeva Dagmara Sultanovna - candidate of technical sciences, docent, Head of the Direction of Microbiology, leading scientific worker of the Laboratory «Hygiene of production and microbiology», The V.M. Gorbatov All-Russian Meat Research Institute 109316, Moscow, Talalikhina str., 26

Tel.: 8-495-676-60-11

E-mail: mminaev@inbox.ru

Minaev Mikhail Yur'evich - candidate of technical sciences, Head of the Direction of PCR, leading scientific worker of the Laboratory "Hygiene of production and microbiology», The V.M. Gorbatov AllRussian Meat Research Institute

109316, Moscow, Talalikhina str., 26

Tel.: 8-495-676-60-11

E-mail: mminaev@inbox.ru

Makhova Anzhelika Alexandrovna - junior researcher of the Laboratory «Hygiene of production and microbiology», The V.M. Gorbatov All-Russian Meat Research Institute

109316, Moscow, Talalikhina str., 26

Tel.: 8-495-676-60-11

E-mail: aeremtsova@gmail.com

\section{Contribution}

Authors equally contributed to the writing of the manuscript and are equally responsible for plagiarism

Bataeva D.S. designed the scientific approaches to performing work, estimated the volume of investigation, analyzed the obtained data, did the descriptive part of the work and made corrections after submission to the editing office.

Minaev M.Yu. designed the scientific approaches to performing work, estimated the volume of investigation, analyzed the obtained data Makhova A.A. selected the subjects of investigation and carried out the experiments.

Conflict of interest

The authors declares no conflict of interest.

Received 25.10.2016 